\title{
Initial Testing Report and Recommendations for Archaeological Resources Along Proposed Loop 1604, Bexar County, Texas
}

Wayne C. Young

Follow this and additional works at: https://scholarworks.sfasu.edu/ita

Part of the American Material Culture Commons, Archaeological Anthropology Commons, Environmental Studies Commons, Other American Studies Commons, Other Arts and Humanities Commons, Other History of Art, Architecture, and Archaeology Commons, and the United States History Commons

Tell us how this article helped you.

This Article is brought to you for free and open access by the Center for Regional Heritage Research at SFA ScholarWorks. It has been accepted for inclusion in Index of Texas Archaeology: Open Access Gray Literature from the Lone Star State by an authorized editor of SFA ScholarWorks. For more information, please contact cdsscholarworks@sfasu.edu. 


\section{Initial Testing Report and Recommendations for Archaeological Resources Along Proposed Loop 1604, Bexar County, Texas}

\section{Licensing Statement}

This is a work produced for the Texas Department of Transportation (TxDOT) by the report producer. TxDOT and the report producer jointly own all rights, title, and interest in and to all intellectual property developed under TXDOT's contract with the report producer. The report may be cited and brief passages from this publication may be reproduced without permission provided that credit is given to both TXDOT and the report producer. Permission to reprint an entire chapter, section, figures or tables must be obtained in advance from either the Supervisor of the Archeological Studies Branch, Environmental Affairs Division, Texas Department of Transportation, 125 East 11th Street, Austin, Texas, 78701 or from the report producer. 
INITIAL TESTING REPORT AND RECOMMENDATIONS FOR ARCHAEOLOGICAL RESOURCES ALONG PROPOSED LOOP 1604, BEXAR COUNTY, TEXAS

Wayne C. Young

State Department of Highways

and Public Transportation

Archaeology Section 


\section{INITIAL TESTING REPORT AND RBCOMMENDATIONS FOR ARCHAEOLOGICAL RESCURCES ALONG PROPOSED LOOP 1604, BEXAR COUNTY, TEXAS}

Archaeological Site 41BX503 is located in southeastern Bexar County along Loop 1604 at the intersection of the Loop and Schultz Road and is 4.2 miles south of the intersection of U.S. 181 and F.M. 1518. The site was discovered on July 13, 1978, by a member of the S. D. H. P. T. professional cultural resources staff and was recommended for testing in accordance with Procedures for the Protection of Historic and Cultural Properties (36 C.F.R., Part 800). Testing was conducted from November 8 through December 6, 1978, by the Department's professional cultural resources staff.

The site is located along the western end of a small second terrace system overlooking the San Antonio River floodplain to the west and south. The floodplain extends .25 mile west and approximately 1.0 mile south to the river. The site is along the eastern side of the river and is within 50 meters of an overflow channel of the river (Figure 1).

Site 41BX503 covers an area 40 meters north-south and 90 meters eastwest, with the western half lying within the proposed Right of Way. Cultural debris was found thinly scattered along the terrace crest in a 40-by40-meter area. This area has been frequently plowed which may have resulted in an exaggeration of the horizontal limits of the site to some extent.

Testing of the site was accomplished through the use of three backhoe trenches along the margins of the site and seven 2-meter squares spaced across the Right of Way (Figure 2). A 11 of the squares were excavated in arbitrary $10-\mathrm{cm}$. levels from the present ground surface after the $20-\mathrm{cm}$. thick plow zone was removed as one level. All soil from the units was screened through 114-inch mesh hardware cloth. 
This Page Redacted Per THC Policy 


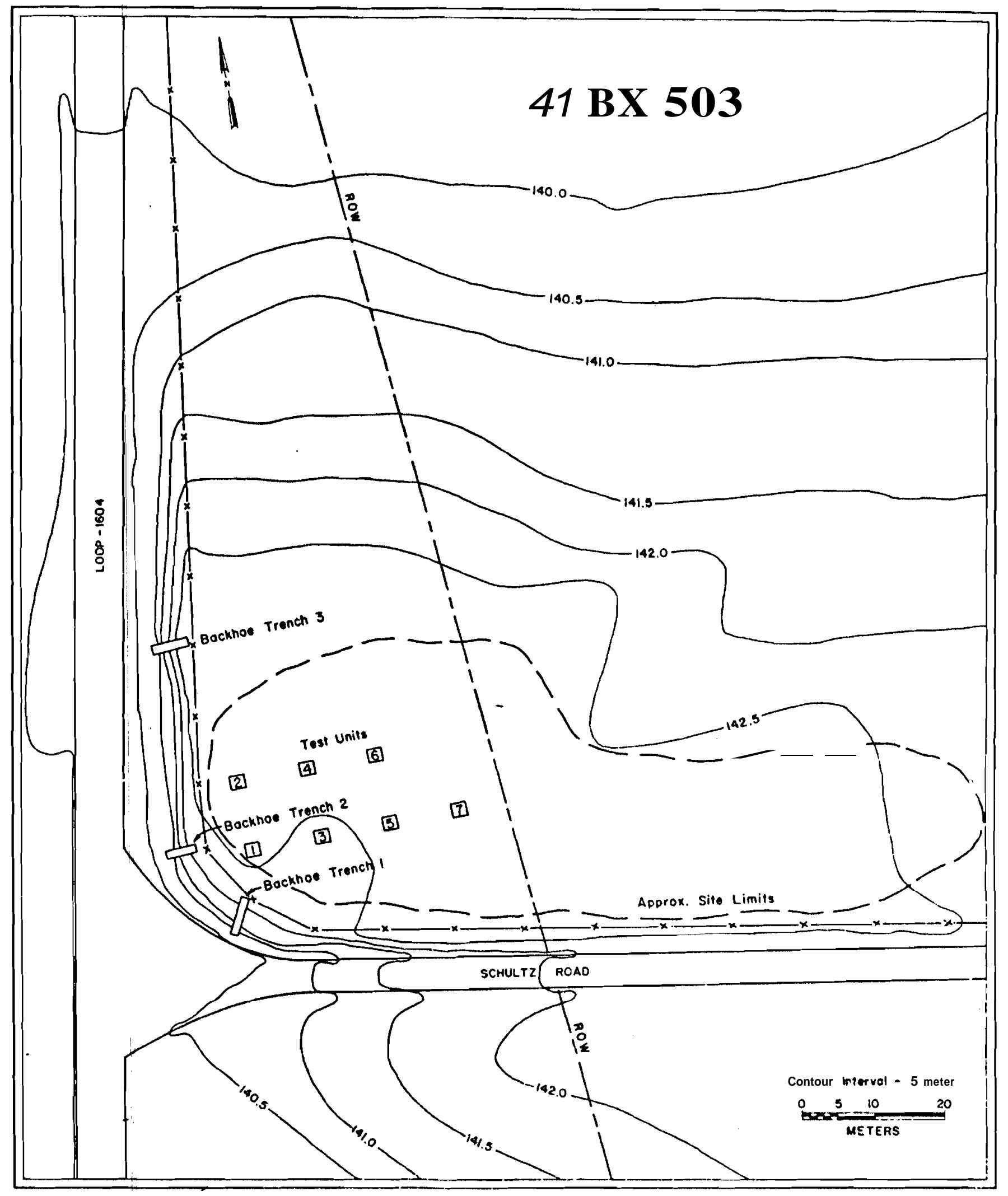

Figure 2. Contour Map of 41BX503 
Soil profiles from the backhoe cuts and the test units revealed that the basic soil was a light tan sandy loam with scattered caliche pebbles extending to a minimum depth of 4 meters below the surface. The backhoe cuts outside the plowed field revealed a $60-\mathrm{cm}$. thick upper zone of brown sandy loamoverlying the light tan sandy loam. This upper zone was not apparent in the test units and is presumed to have eroded away and tohave mixed with the lower deposits due to plowing activities. Selected soil profiles are illustrated in Figure 3.

Cultural debris was not apparent in the backhoe trenches and was largely limited to the top four levels, or $50 \mathrm{~cm}$., in the hand-excavated units. The bulk of the recovered materials was found in the plow zone with a rapid drop indensity of materials'in each succeeding level. The plow gone yielded $61.2 \%$ of the recovered debris, Level 2 contained $25.8 \%$, Level 3 had 10\%, and Level 4 produced 2.8\%. Levels 5 through 8 contained less than $1 \%$ each. Cores and chipped stone tools were recovered from only the upper $30 \mathrm{~cm}$. , and $86.6 \%$ of these were from the plow zone. Historic debris, consisting primarily of glass and crockery, was recovered from the upper three levels $(40 \mathrm{~cm}$.) in the same zones showing the highest density of flakes, cores, and chipped stone tools. Material distributions are shown in Figure 4.

The cultural occupations at Site 41BX503 do not appear to exceed $40 \mathrm{~cm}$. in depth and are more likely limited to the upper $30 \mathrm{~cm}$. Some mixing is evident by the freshly plowed field with the $20-\mathrm{cm}$. deep plow zone and by some historic materials found as deep as $40 \mathrm{~cm}$.

Approximately $1 \%$ of the site within the Right of Way was tested, and a very low yield of chipped stone tools and cores was recovered. A total of 37 levels was excavated; and only 4 biface fragments, 1 preform, and 11 cores were recovered. No diagnostic artifacts were found beneath the 


\section{$41 \mathrm{BX} 503$}

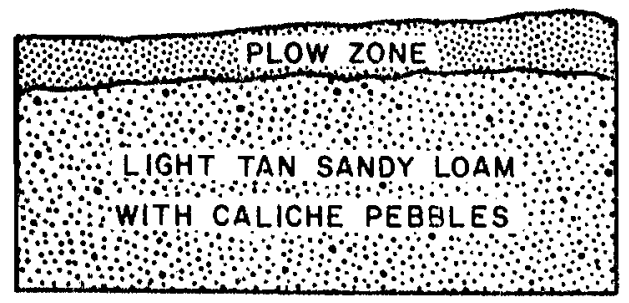

Test Unit 1
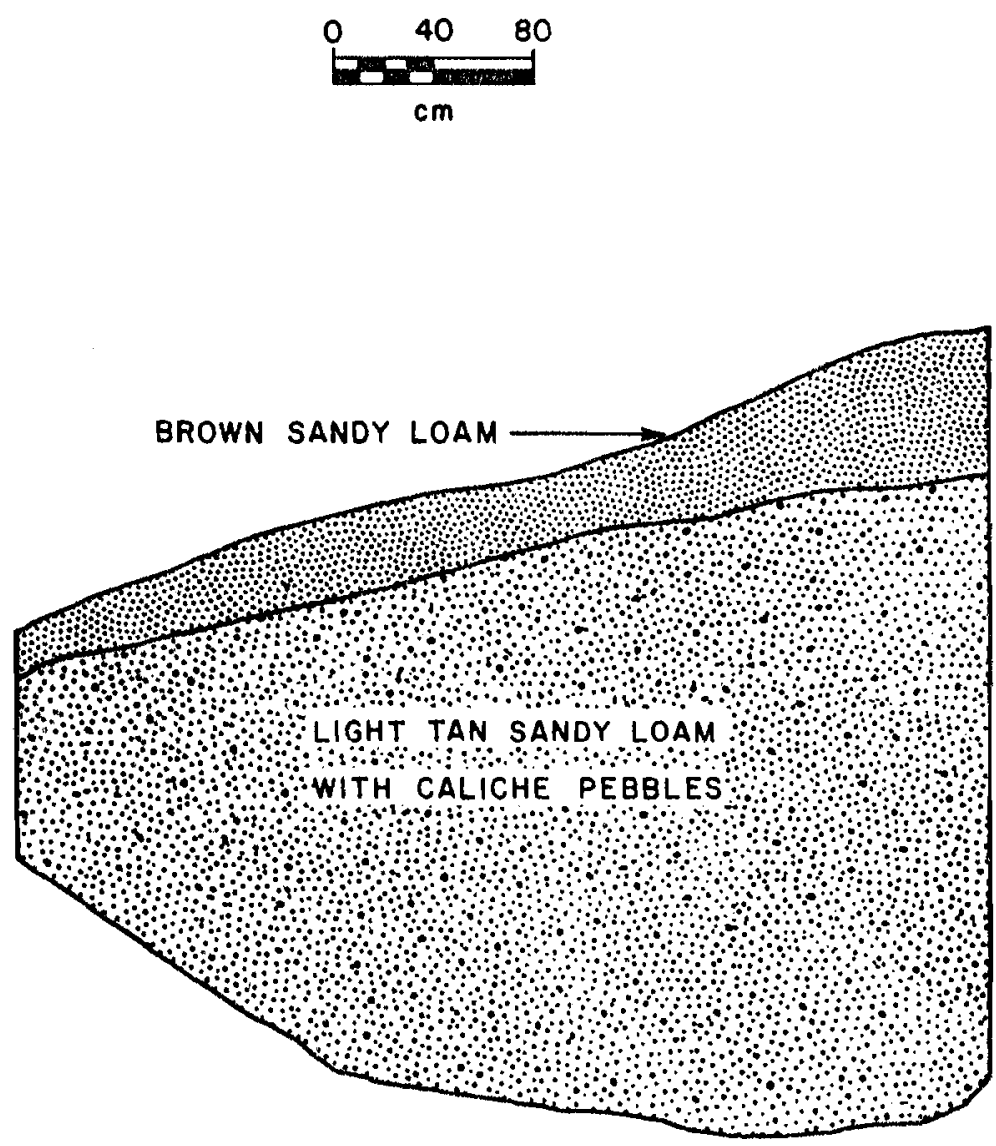

Backhoe Trench I

Figure 3. Soil Profiles (41BX503) 


\begin{tabular}{|c|c|c|c|c|c|c|c|}
\hline Level & $\begin{array}{c}\text { Test } \\
\text { Unit: } \\
1\end{array}$ & $\begin{array}{c}\text { Test } \\
\text { Unit } \\
2\end{array}$ & $\begin{array}{c}\text { Test } \\
\text { Unit } \\
3\end{array}$ & $\begin{array}{c}\text { Test } \\
\text { Unit } \\
4\end{array}$ & $\begin{array}{c}\text { Test } \\
\text { Unit } \\
5\end{array}$ & $\begin{array}{c}\text { Test } \\
\text { Unit } \\
6\end{array}$ & $\begin{array}{c}\text { Test } \\
\text { Unit } \\
7\end{array}$ \\
\hline & \multicolumn{7}{|c|}{ Flake Counts } \\
$0-20 \mathrm{~cm}$ & 19 & 188 & 85 & 103 & 245 & 127 & 327 \\
$20-30 \mathrm{~cm}$ & 55 & 96 & 33 & 5 & 92 & 49 & 143
\end{tabular}

\begin{tabular}{|c|c|c|c|c|c|c|c|c|}
\hline $\begin{array}{l}50-60 \\
60-70 \\
70-80 \\
80-90\end{array}$ & $\begin{array}{l}\mathrm{cm} \\
\mathrm{cm} \\
\mathrm{cm} \\
\mathrm{cm}\end{array}$ & $\begin{array}{l}2 \\
0 \\
1 \\
0\end{array}$ & $\begin{array}{r}12 \\
6 \\
0 \\
1\end{array}$ & \multicolumn{5}{|c|}{0} \\
\hline & & \multicolumn{7}{|c|}{ Cores and Chipped Stone Tools } \\
\hline $0-20$ & $\mathrm{~cm}$ & 1 & 1 & 0 & 4 & 5 & 2 & 0 \\
\hline $20-30$ & $\mathrm{~cm}$ & 1 & 0 & 0 & 0 & 1 & 0 & 0 \\
\hline $30-90$ & $\mathrm{~cm}$ & 0 & 0 & 0 & 0 & 0 & 0 & $\mathrm{O}$ \\
\hline \multicolumn{9}{|c|}{ Historic Debris } \\
\hline $0-20$ & $\mathrm{~cm}$ & 2 & 7 & 2 & 1 & 9 & 4 & 1 \\
\hline $20-30$ & $\mathrm{~cm}$ & 1 & 1 & 0 & 0 & 2 & 0 & 0 \\
\hline $30-40$ & $\mathrm{~cm}$ & 0 & 0 & 1 & 0 & 0 & 0 & 0 \\
\hline $40-90$ & $\mathrm{~cm}$ & 0 & 0 & 0 & 0 & 0 & 0 & 0 \\
\hline
\end{tabular}

$\begin{array}{crcc}\text { Level } & \begin{array}{r}\text { Average } \\ \text { Flakes }\end{array} & \begin{array}{c}\text { Total } \\ \text { Cores/Tools }\end{array} & \begin{array}{c}\text { Total } \\ \text { Historic Debris }\end{array} \\ 0-20 \mathrm{~cm} & 156.2 & 13 & 26 \\ 20-30 \mathrm{~cm} & 67.5 & 2 & 4 \\ 30-40 \mathrm{~cm} & 26.4 & 0 & 1 \\ 40-50 \mathrm{~cm} & 7.4 & 0 & 0 \\ 50-60 \mathrm{~cm} & 4.6 & 0 & 0 \\ 60-70 \mathrm{~cm} & 3.0 & 0 & 0 \\ 70-80 \mathrm{~cm} & 0.5 & 0 & 0 \\ 80-90 \mathrm{~cm} & 0.5 & 0 & 0\end{array}$

Figure 4. Distribution of Cultural Materials (41BX503) 
the surface although 4 were found on top. Daily surface examinations in a clean field produced only 1 Bulverde, 1 Lerma, 1 Tortugas, and 1 Fairland point, along with 4 biface fragments and 7 cores. Selected artifacts are illustrated in Figure 5.

This low recovery rate of tools is taken to be indicative of a small and short-term prehistoric occupation(s) at Site 41BX503. If the recovered sample can be considered representative of the site, the high ratio of cores to tools (18:13) may indicate that the primary activity at the site was lithic reduction of stream-rolled flint cobbles. Features, such as burned rocks and hearths, were notably absent; and the lack of these items may indicate short-term utilization of the area.

Site 41BX503 appears to be a minor Archaic site with a major emphasis on core reduction. The site shows some mixing due to plowing activities, and some downward movement of cultural debris is also expected in the sandy soils. The deposits appear shallow, with most of the site disturbed by plowing. These disturbances and the seemingly minor nature of the occupation indicate that the site has little significance in Texas prehistory.

Site 41BX503 does not meet the criteria for nomination to the National Register of Historic Places, and further archaeological mitigation is not warranted. 


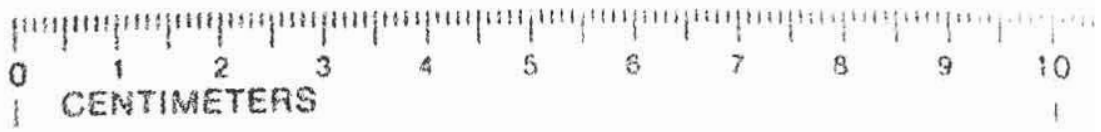
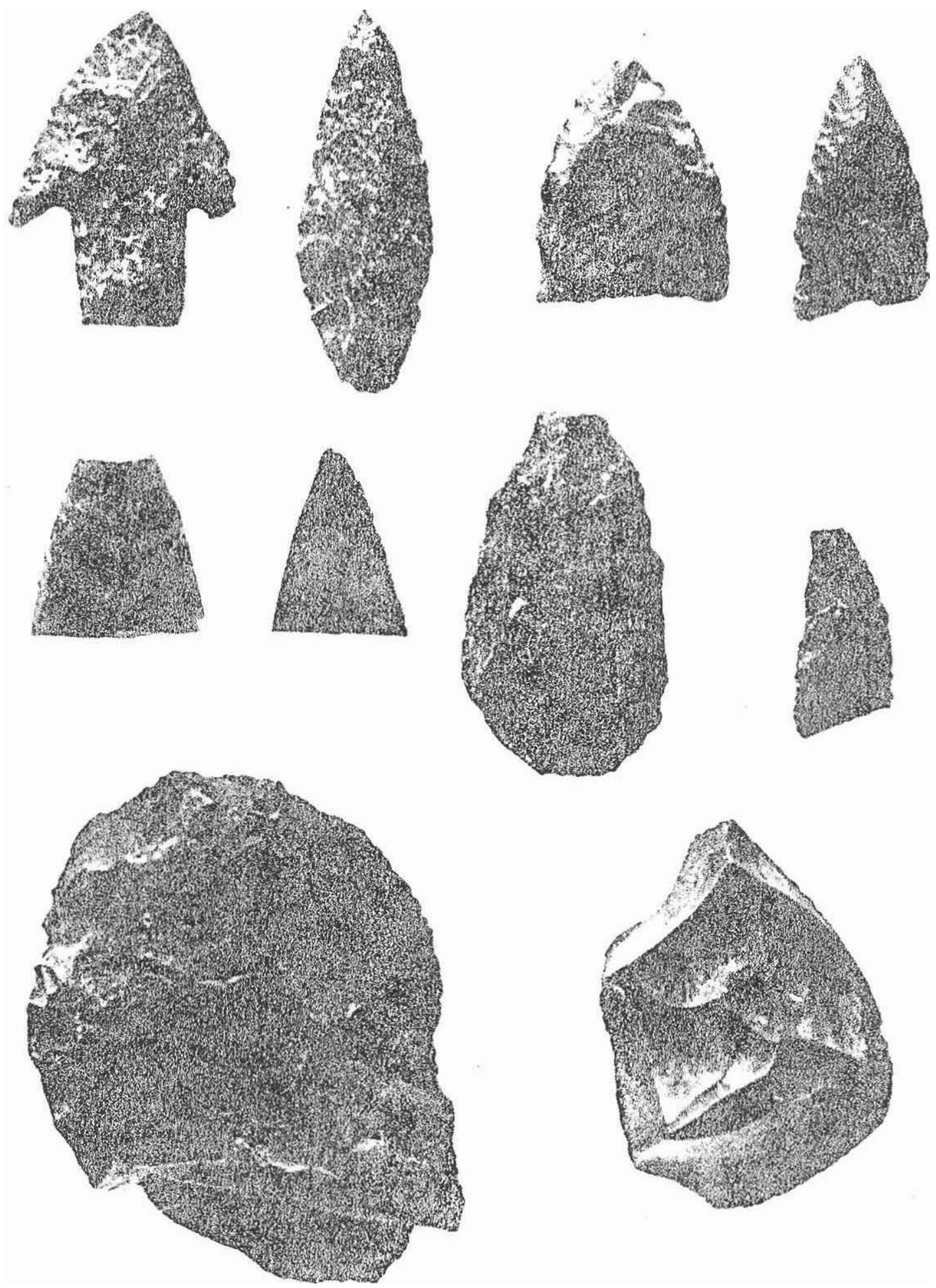

Figure 5. Selected A rtifacts (41BX503) 